\title{
Role of Interleukin 10 in Specific Immunotherapy
}

\author{
Cezmi A. Akdis, ${ }^{*}$ Thorsten Blesken, ${ }^{*}$ Mübeccel Akdis, ${ }^{*}$ Brunello Wüthrich, ${ }^{\ddagger}$ and Kurt Blaser ${ }^{*}$ \\ *Swiss Institute of Allergy and Asthma Research, CH-7270 Davos, Switzerland; and ${ }^{\ddagger}$ Allergy Unit, Department of Dermatology, \\ University of Zurich, $\mathrm{CH}-8091$ Zurich, Switzerland
}

\begin{abstract}
The induction of allergen-specific anergy in peripheral $\mathrm{T}$ cells represents a key step in specific immunotherapy (SIT). Here we demonstrate that the anergic state results from increased IL-10 production. In bee venom (BV)-SIT the specific proliferative and cytokine responses against the main allergen, the phospholipase $A_{2}$ (PLA), and $T$ cell epitopecontaining PLA peptides were significantly suppressed after $7 \mathrm{~d}$ of treatment. Simultaneously, the production of IL-10 increased during BV-SIT. After $28 \mathrm{~d}$ of BV-SIT the anergic state was established. Intracytoplasmic cytokine staining of PBMC combined with surface marker detection revealed that IL-10 was produced initially by activated $\mathrm{CD} 4^{+} \mathrm{CD} 25^{+}$, allergen-specific $\mathrm{T}$ cells, and followed by $\mathrm{B}$ cells and monocytes. Neutralization of IL-10 in PBMC fully reconstituted the specific proliferative and cytokine responses. A similar state of IL-10-associated T cell anergy, as induced in BVSIT, was found in hyperimmune individuals who recently had received multiple bee stings. The addition of IL-10 to soluble CD40 ligand IL-4-stimulated PBMC or purified $B$ cells inhibited the PLA-specific and total IgE and enhanced the IgG4 formation. Accordingly, increased IL-10 production by SIT causes specific anergy in peripheral T cells, and regulates specific IgE and IgG4 production toward normal IgG4-related immunity. (J. Clin. Invest. 1998. 102:98106.) Key words: immunotherapy • interleukin 10 - anergy • $\mathrm{T}$ cell epitopes $\bullet$ isotype regulation $\bullet$ bee venom allergy
\end{abstract}

\section{Introduction}

It is well established that allergy is associated with high serum levels of allergen-specific $\mathrm{IgE}$ and eosinophilia that are induced by a spectrum of Th2 type cytokines. In particular, generation of IL-4 and IL-13 is associated with IgE production and IL-5 with increased eosinophil numbers (1-3). In contrast, normal immunity to allergen is characterized by the predominant $\mathrm{IgG}$ antibody formation, especially of the IgG4 class (4). $\mathrm{IgG} 4$, like $\mathrm{IgE}$, requires IL-4 for isotype switch. The production of IgG4 antibodies by memory B cells depends on the presence of IFN- $\gamma$, whereas IgE remains IL-4 dependent and is

Address correspondence to Cezmi A. Akdis, M.D., Swiss Institute of Allergy and Asthma Research (SIAF), Obere Strasse 22, CH-7270 Davos, Switzerland. Phone: 41-81-413-70-83; FAX: 41-81-413-16-07; E-mail: akdisac@siaf.unizh.ch

Received for publication 12 November 1997 and accepted in revised form 4 May 1998.

J. Clin. Invest.

(C) The American Society for Clinical Investigation, Inc. 0021-9738/98/07/0098/09 \$2.00

Volume 102, Number 1, July 1998, 98-106

http://www.jci.org suppressed by IFN- $\gamma$ (5-7). IL-10 is a major regulatory cytokine of inflammatory responses. It was identified originally as an inhibitor of IFN- $\gamma$ and IL-2 synthesis in Th1 cells. However, IL-10 was found to be a general inhibitor of proliferative and cytokine responses in T cells and is produced by mononuclear phagocytes $(8,9)$, natural killer cells $(10)$, and by both Th1 and Th2 type lymphocytes (11). It can suppress cytokine synthesis in $\mathrm{T}$ cells by inhibiting accessory CD28/B7.1 receptor interaction (12).

The response to the soluble phospholipase $\mathrm{A}_{2}(\mathrm{PLA})^{1}$ of bee venom $(\mathrm{BV})$ represents a well suited human model to study regulatory mechanisms of cytokine- and antigen-specific $\mathrm{IgE}$ and $\mathrm{IgG}$ antibodies. PLA represents the major antigen and allergen in individuals sensitized to bee sting and can induce both allergy and normal immunity $(13,14)$. Normally, at an initial response to bee sting, low-affinity IgG1 anti-PLA antibodies are elicited (4). Repeated exposure to BV generates high-affinity IgG4 anti-PLA antibodies $(4,15,16)$. In contrast, individuals allergic to bee sting develop excessive $\operatorname{IgE}$ antibodies mainly to PLA $(13,14)$.

Although specific immunotherapy (SIT) is applied frequently in allergy to hymenoptera venom, the mechanisms by which clinical improvement is achieved in allergic patients remain to be elucidated. Stimulation of IgG4 antibodies and a decline of the IgE/IgG4 anti-PLA antibody ratio (15-20) were claimed to be responsible for successful SIT. Also, the generation of IgE downregulating $\mathrm{CD}^{+} \mathrm{T}$ cells and reduced numbers of mediator-secreting mast cells and eosinophils (21-25) were found in SIT. Moreover, successful SIT of allergic rhinitis was shown to be associated with decreased numbers of Th2 and increased IFN- $\gamma$-producing cells (26). A shift from a Th2 cytokine pattern toward increased IFN- $\gamma$ production in SIT of allergy to BV, Lol p, and Der p (26-29) indicated an important involvement of cytokine-producing $\mathrm{CD}^{+} \mathrm{T}$ cells. However, the induction of an anergic state in peripheral $\mathrm{T}$ cells, which is characterized by suppressed proliferative and cytokine responses against the major allergen(s), appeared to be a pivotal step in SIT (30).

In this study we demonstrate that the induction and maintenance of epitope-specific T cell anergy is associated with increased IL-10 production. At the beginning of a so-called ultra-rush SIT and initiation of anergy, IL-10 was mostly produced by PLA-specific T cells. The anergic state was maintained by IL-10 production in B cells and monocytes. Increased IL-10 production also accounts for a change in PLAspecific $\mathrm{IgE}$ and $\mathrm{IgG} 4$ ratio in favor of $\mathrm{IgG} 4$. Interestingly, such a state of naturally induced tolerance could be observed in hyperimmune subjects who had been frequently stung by bees, such as beekeepers.

1. Abbreviations used in this paper: APC, antigen-presenting cells; $\mathrm{BV}$, bee venom; PLA, bee venom phospholipase $\mathrm{A}_{2}$; sCD40L, soluble CD40 ligand; SIT, specific immunotherapy; TT, tetanus toxoid. 


\section{Methods}

Study population. $12 \mathrm{BV}$ allergic individuals (mean age: $29 \mathrm{yr}$ ) with a history of severe systemic allergic reactions of grade III-IV $(31,32)$ after a bee sting were studied. All patients demonstrated positive intracutaneous reactions to honey BV (Pharmalgen Venom, ALK, Horsholm, Denmark) at a concentration of $<10^{-4} \mathrm{~g} /$ liter and BVspecific serum IgE antibodies $>2 \mathrm{kU} /$ liter as estimated by CAP immunoassay (Pharmacia Diagnostics AG, Uppsala, Sweden). Blood samples were taken before BV-SIT and 1, 7, and $28 \mathrm{~d}$ after starting BV-SIT. Two healthy nonallergic BV hyperimmune subjects (beekeepers, age 37 and $57 \mathrm{yr}$ ), who had been stung $>20$ times by bees during the last $2 \mathrm{mo}$, were included in the study.

Reagents. PLA was from Boehringer-Mannheim (Mannheim, Germany). T cell epitope-containing peptides PLA ${ }^{45-62}$ (PI), PLA ${ }^{81-92}$ (PII), and PLA ${ }^{113-124}$ (PIII) were synthesized by Drs. C.H. Schneider and H.P. Rolli (Institute for Clinical Immunology and Allergology, Inselspital, University of Bern, Switzerland) by solid phase synthesis and subsequent HPLC purification (33). The three peptides did not bind anti-PLA antibodies of any isotype and did not show any skin test reactivity. Tetanus toxoid (TT) was from the Swiss Serum and Vaccine Institute (Bern, Switzerland). Recombinant human IL-2 and IL-4 were from Novartis (Basel, Switzerland). IL-10 and rabbit anti-IL-10 were from PeproTech Inc. (Rocky Hill, NJ) and mouse anti-IL-10 JES3-9D7 was from PharMingen (San Diego, CA). Soluble CD40 ligand (sCD40L) was obtained from the transfected cell line 8-40-1, generated by Dr. P. Lane (34) (sCD40L-CD8- $\alpha$ fusion protein; Institute for Immunology, Basel, Switzerland), and cultured for $3 \mathrm{~d}$ in CG medium (Vitromex, Vilshofen, Germany). The sCD40L activity was standardized according to highest $\operatorname{IgE}$ inducing capacity in a 12-d PBMC culture costimulated with $25 \mathrm{ng} / \mathrm{ml}$ of IL-4 (35). Supernatants from the corresponding untransfected cell line $\mathrm{J} 558 \mathrm{~L}$ (kindly provided by Dr. M. Reth, University of Freiburg, Freiburg, Germany) were used as controls.

$B V$-SIT. Under intensive care conditions $0.1,1,10$, and $20 \mu \mathrm{g}$ of BV (ALK) were administered subcutaneously in the upper arms at 30-min intervals and then 30 and $50 \mu \mathrm{g}$ at 60 -min intervals, reaching a cumulative dose of $111.1 \mu \mathrm{g}$. On day 7 , two booster injections of $50 \mu \mathrm{g}$ were administered, followed by $100-\mu \mathrm{g}$ boosters given at 4 -wk intervals (32).

$T$ cell cultures. PBMC were isolated by Ficoll (Biochrom, Berlin, Germany) density gradient centrifugation of peripheral venous blood. Cells were washed three times and resuspended in RPMI 1640 medium supplemented with $1 \mathrm{mM}$ sodium pyruvate, $1 \%$ MEM nonessential amino acids and vitamins, $2 \mathrm{mM}$ L-glutamine, $100 \mathrm{U} / \mathrm{ml}$ penicillin, $100 \mu \mathrm{g} / \mathrm{ml}$ streptomycin, $50 \mu \mathrm{M}$ 2-ME (all from Life Technologies, Basel, Switzerland), and 10\% heat-inactivated FCS (Sera-Lab, Sussex, United Kingdom). As described previously $(5,30), 10^{6}$ cells/ $\mathrm{ml}$ were stimulated in a 24 -well plate with $1 \mu \mathrm{M}$ of PLA, $3 \mu \mathrm{M}$ of PLA peptides I, II, and III, or $0.01 \mathrm{U} / \mathrm{ml}$ TT. Supernatants were harvested on day 5 for cytokine detection and parallel cultures were expanded in medium supplemented with a mixture of IL-2 $(25 \mathrm{U} / \mathrm{ml})$ and IL-4 $(25 \mathrm{ng} / \mathrm{ml})$. After $12 \mathrm{~d}$, cells were washed three times with PBS and $10^{6}$ cells were restimulated with the same antigen at the same concentrations as before, in the presence of $10^{6}$ autologous, 3,000 rad irradiated PBMC in 24-well tissue culture plates, in duplicates. Previously it was demonstrated that stimulation of PBMC with antigen, expansion of the responding antigen-specific T cells by IL-2 and IL-4, and boosting with the same antigen allowed the detection of antigen-induced IL-4, and conferred the same cytokine pattern as observed in the primary response for IL-5, IL-10, IL-13, and IFN- $\gamma(30)$. According to previous kinetic studies, supernatants were harvested $16 \mathrm{~h}$ later for determination of IL-4 and $48 \mathrm{~h}$ later for IL-5, IL-10, IL-13, and IFN- $\gamma(5,30)$. To determine T cell proliferative response, $2 \times 10^{5}$ PBMC were stimulated with $1 \mu \mathrm{M}$ PLA, a $3 \mu \mathrm{M}$ mixture of the three PLA T cell epitope peptides, and $0.01 \mathrm{U} / \mathrm{ml}$ TT in $200 \mu \mathrm{l}$ medium in 96-well flat-bottomed tissue culture plates in triplicates for $6 \mathrm{~d}$ and pulsed for $20 \mathrm{~h}$ with $1 \mu \mathrm{Ci}$ of $\left[{ }^{3} \mathrm{H}\right]$ thymidine (DuPont/New England
Nuclear, Boston, MA). Incorporation of the labeled nucleotide was determined after $20 \mathrm{~h}$ in a LKB beta plate reader (Wallac-Phormacia, Turku, Finland). IL-10 was neutralized in cultures with $20 \mu \mathrm{g} / \mathrm{ml} \mathrm{rab-}$ bit anti-IL-10 or anti-IL-10 mAb JES3-9D7. Rabbit IgG (Sigma Chemical Co., St. Louis, MO) or mouse IgG1 (Coulter Corp., Miami, FL) served as a control antibody.

Quantification of cytokines. The solid-phase sandwich ELISAs for IFN- $\gamma$, IL-4, IL-5, IL-10, and IL-13 have been described previously $(5,6,30)$. In brief, 96-well microtiter plates (Maxisorb; Nunc, Roskilde, Denmark) were coated with mAb 43-11 to human IFN- $\gamma$ and developed with biotinylated mAb 45-15. The sensitivity of the IFN- $\gamma$ ELISA was $<10 \mathrm{pg} / \mathrm{ml}$ (mAbs and IFN- $\gamma$ standard were gifts from Dr. S.S. Alkan, Novartis).

IL-4 was measured by using mAb $3 \mathrm{H} 4$ for coating and biotinylated $\mathrm{mAb} 8 \mathrm{~F} 12$ for detection (mAbs and IL-4 standard were provided by Dr. C.H. Heusser, Novartis).

IL-5 was determined by using mAb TRFK5 for coating and biotinylated mAb JES15A10 for detection (mAbs and IL-5 standard were from PharMingen). The detection limit of the IL-5 ELISA was $50 \mathrm{pg} / \mathrm{ml}$.

IL-10 was determined by using a combination of mAb JES3-9D7 and biotinylated JES3-12G8 (mAb and rIL-10 standard were from PharMingen). The sensitivity of the IL-10 ELISA was $\leq 50 \mathrm{pg} / \mathrm{ml}$. The IFN- $\gamma$, IL-4, IL-5, and IL-10 ELISAs were developed by peroxidase-labeled ExtrAvidine (Sigma Chemical Co.), and $o$-phenylendiamine $\mathrm{HCl}$ in citrate buffer, $\mathrm{pH}$ 5.5, was used as a substrate. Optical density was measured at $490 \mathrm{~nm}$ in an ELISA reader (Molecular Devices, Menlo Park, CA) after stopping the reaction with $0.5 \mathrm{~N} \mathrm{H}_{2} \mathrm{SO}_{4}$.

For the detection of IL-13 the mAb JES10-2F9 (kindly provided by DNAX Research Institute, Palo Alto, CA) was used for coating. Recombinant IL-13 from PeproTech Inc. was used as a standard. Rabbit anti-IL-13 (PeproTech Inc.) and alkaline phosphatase-labeled goat anti-rabbit antibodies (Zymed Laboratories Inc., South San Francisco, CA) were used for detection. The detection limit was 300 $\mathrm{pg} / \mathrm{ml}$ of IL-13. In this case, the chromogenic substrate was 4-nitrophenyl-phosphate-disodium-hexahydrate (E. Merck, Darmstadt, Germany) in diethanolamine buffer, $\mathrm{pH}$ 9.8. Optical density was measured at $405 \mathrm{~nm}$.

Detection of intracytoplasmic $I L-10$. Immediately after purification of PBMC, intracellular IL-10 was stained by fixing and permeabilizing the cells with a paraformaldehyde and saponin solution (PermeaFix $^{\mathrm{TM}}$, Ortho Diagnostic Systems Inc., Raritan, NJ) (36). After washing with PBS containing 5\% FCS, $1.5 \%$ BSA (Sigma Chemical Co.), and $0.0055 \%$ EDTA (Fluka Chemie AG, Buchs, Switzerland), cells were incubated with $0.5 \mu \mathrm{g} / \mathrm{ml}$ PE-labeled anti-IL-10, or PE-labeled rat IgG1 control antibodies (all from PharMingen) for 40 min at room temperature. IL-10-containing monocytes were determined with anti-CD14-FITC, B cells with anti-CD19-FITC, and activated $\mathrm{CD}^{+} \mathrm{T}$ cells with anti-CD4-ECD and anti-CD25-FITC for 30 min at room temperature. The multicolor fluorescence analysis was performed on an Epics Profile (Coulter Corp.) with Argon laser (488 $\mathrm{nm}$ ). Emitted fluorescence was determined by means of 525-nm, 575$\mathrm{nm}$, and $635-\mathrm{nm}$ band filters. The intracytoplasmic IL-10 content of specifically stimulated PBMC was analyzed at day 10 of culture after a 5-h stimulation with a mixture of $4 \mu \mathrm{g} / \mathrm{ml}$ anti-CD3 (Ortho Diagnostic Systems Inc.) and anti-CD28 mAbs (CLB, Amsterdam, The Netherlands), in the presence of $2 \mu \mathrm{M}$ monensin (Sigma Chemical Co.).

Generation of $\operatorname{IgE}$ and $\operatorname{Ig} G 4$ anti-PLA in vitro. As described previously $(5,30)$, PBMC $\left(2.5 \times 10^{6} /\right.$ well per $\left.5 \mathrm{ml}\right)$ were cultured in 6-well tissue culture plates in the presence of $0.1 \mathrm{ng} / \mathrm{ml}$ of PLA, $25 \mathrm{ng} / \mathrm{ml} \mathrm{IL-4,}$ and $25 \%$ sCD40L-containing 8-40-1 cell supernatant in the above medium, which was further supplemented with $40 \mu \mathrm{g} / \mathrm{ml}$ human transferrin and $4 \mu \mathrm{g} / \mathrm{ml}$ bovine insulin (both from Sigma Chemical Co.). $\mathrm{B}$ cells were purified from PBMC using the magnet activated cell separation system (MACS ${ }^{\circledR}$; Miltenyi Biotech, Marburg, Germany) and anti-CD19 mAb after depletion of monocytes by anti-CD14 as described $(5,7,37)$. The purity of cells was $>95 \%$ as determined by FACS $^{\circledR}$ analysis with FITC-labeled anti-CD19 (Coulter Corp.). B cells 
were stimulated with IL-4 and sCD40L (50,000/well in $200 \mu \mathrm{l})$ in 96-well tissue culture plates. IL-10 was added in different concentrations to the PBMC and B cell cultures. Supernatants were harvested at day 12 for determination of PLA-specific and total $\operatorname{IgE}$ and $\operatorname{IgG} 4$ antibodies.

Quantification of specific antibodies and total Ig isotypes. The $\operatorname{IgE}$ and IgG4 anti-PLA antibody contents in serum and culture supernatants were measured in duplicates by ELISA $(5-7,30)$. PLA-specific antibodies were detected in ELISA plates (Maxisorb; Nunc) coated with $0.5 \mu \mathrm{g} /$ well PLA and incubated with culture supernatants at different dilutions. Biotinylated anti-IgE mAb 6-7 (Novartis) and peroxidase-labeled ExtrAvidine (Sigma Chemical Co.) were used to develop IgE anti-PLA. Anti-IgG4 mAb RJ4 (Oxoid Ltd., Basingstoke, United Kingdom) and peroxidase-labeled anti-mouse Ig antibodies (Tago, Burlingame, CA) were used in IgG4 anti-PLA ELISA. Sera from BV allergic patients, calibrated by BV RAST (Pharmacia Diagnostics AG), were used as IgE anti-PLA standards. Human PLA-specific IgG4 mAb BVA2 (38) was used as an IgG4 anti-PLA standard. The sensitivity of these assays was $<0.1 \mathrm{ng} / \mathrm{ml}$ of IgE and IgG4 antiPLA. Total IgE and IgG4 were assayed by sandwich ELISA as described $(5-7,30)$.

Statistical analysis. Student's $t$ test for paired samples was used for statistical analysis to compare results at different time points of immunotherapy.

\section{Results}

Epitope-specific $T$ cell anergy in BV-SIT is associated with IL10 production. Recently, we have shown that BV-SIT induces peripheral anergy in T cells to PLA (26). Therefore, we have investigated the changes in specific $\mathrm{T}$ cell responsiveness to
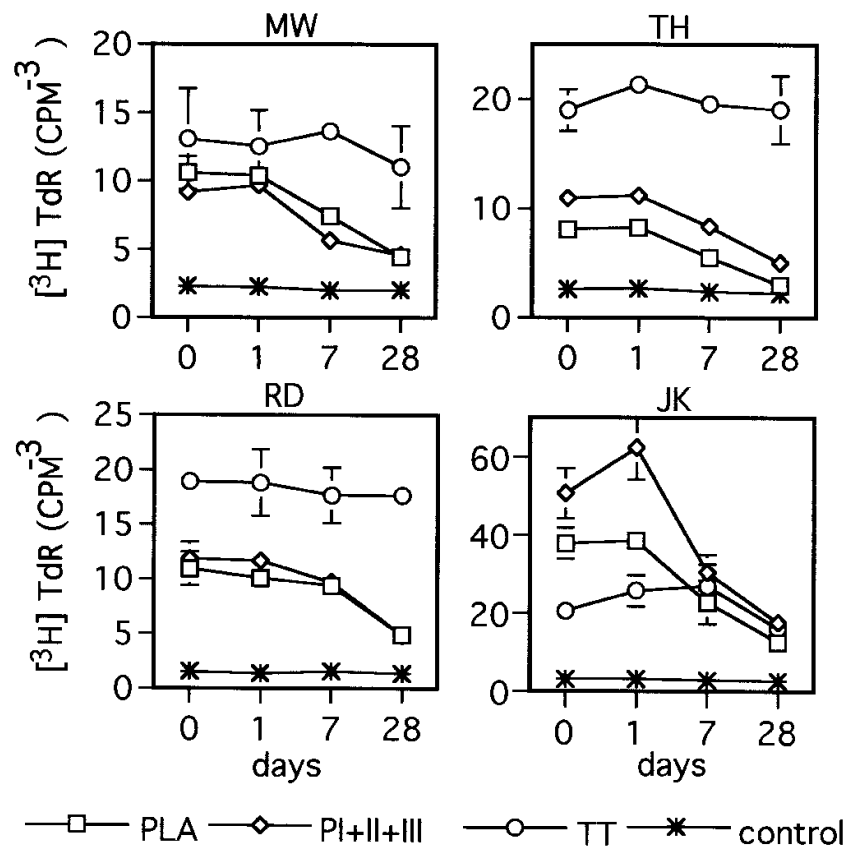

Figure 1. Changes of specific proliferative responses in PBMC during $\mathrm{BV}$-SIT. PBMC of four BV-allergic patients were stimulated with PLA, three PLA T cell epitope-containing peptides $(P I+I I+I I I)$ or control Ag (TT) before and after 1, 7, and $28 \mathrm{~d}$ of BV-SIT. $\left[{ }^{3} \mathrm{H}\right]$ Thymidine incorporation was measured after $7 \mathrm{~d}$. Results shown are mean \pm SD of triplicate cultures. Proliferation to PLA and the PI + PII + PIII mixture decreased significantly after $7 \mathrm{~d}(P<0.05)$ and fully after $28 \mathrm{~d}(P<0.001)$. The TT-specific proliferation remained at initial levels.
PLA during the first month of BV-SIT. Both the intact PLA and an equimolar mixture of the three PLA peptides PI, PII, and PIII specifically induced $\mathrm{T}$ cell proliferation before $\mathrm{BV}$ SIT (Fig. 1). Significantly decreased values of specific proliferative responses were first measured after $7 \mathrm{~d}$ of treatment $(P<$ $0.05)$ in all four patients. After $28 \mathrm{~d}$, the response to both PLA and PLA peptides was suppressed $(P<0.001)$. The response to the TT control antigen was not affected.

As demonstrated in Fig. 2, in parallel to the proliferative response, PLA-induced IL-5, IL-13, and IFN- $\gamma$ production in PBMC was suppressed after $28 \mathrm{~d}$ of BV-SIT $(P<0.001)$, as measured in 5-d cultures. Simultaneous to the induction of specific anergy in T cells, the PLA-induced secretion of IL-10 increased significantly within $7 \mathrm{~d}$ of BV-SIT $(P<0.001)$. IL-4 was not detectable in these cultures and IL-5, IL-13, and IFN- $\gamma$ quantities were at borderline. To determine cytokine production more accurately, the specific cells in antigen-stimulated PBMC cultures were expanded for $12 \mathrm{~d}$ as described (30) (Fig. 3). Again, stimulation by the same antigen as in the primary response demonstrated induction of peripheral $\mathrm{T}$ cell anergy and simultaneous production of IL-10. The decrease in IL-4, IL-5, IL-13, and IFN- $\gamma(P<0.05)$ and increase in IL-10 $(P<$ $0.001)$ were significant after $7 \mathrm{~d}$ of BV-SIT. After $28 \mathrm{~d}$, the PLA and epitope peptide induced production of IFN- $\gamma$, and the Th2 cytokines IL-4, IL-5, and IL-13 were significantly suppressed $(P<0.001)$. In contrast, the cytokine profile in response to the TT control was not affected, indicating specific anergy induction by BV-SIT (Fig. 3).

Increase of IL-10 in BV-IT originates initially from activated T cells and is followed by B cells and monocytes. The cellular source of IL-10 production was determined by multicolor FACS $^{\circledR}$ analysis as shown in Fig. $4 A$. Intracytoplasmic IL-10 staining of freshly purified PBMC and coexpression of surface markers were analyzed before and on days 7 and 28 of BV-SIT. CD ${ }^{+} \mathrm{CD} 25^{+} \mathrm{T}$ cells were gated for IL-10 content immediately after isolation of the PBMC. In PBMC CD4 $4^{+} \mathrm{CD} 25^{+}$ represent in vivo activated $\mathrm{T}$ lymphocytes. Increased intracellular IL-10 production in these activated $\mathrm{CD}^{+} \mathrm{CD} 25^{+} \mathrm{T}$ lymphocytes was first observed on day 7 of BV-SIT. The per-

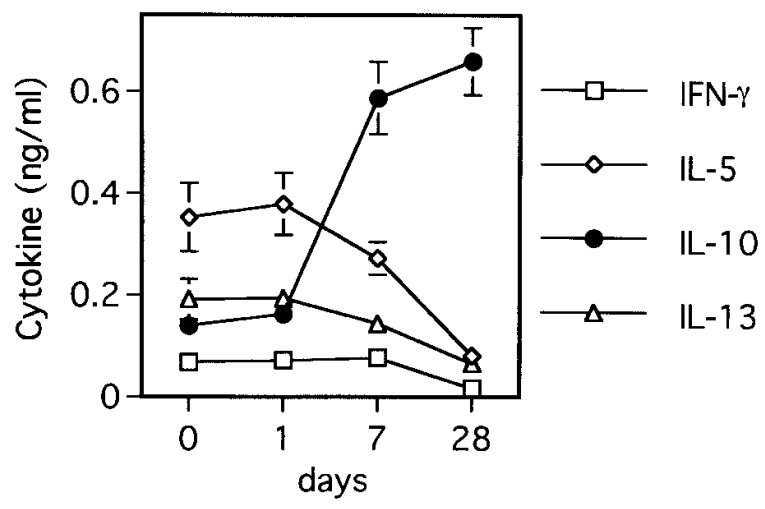

Figure 2. Changes of cytokine production in PBMC cultures during BV-SIT. PBMC were stimulated with PLA, before and after 1, 7, and $28 \mathrm{~d}$ of BV-SIT. Cytokines were determined in supernatants taken after $5 \mathrm{~d}$ of culture. IL-5, IL-13, and IFN- $\gamma$ decreased continuously, while simultaneously IL-10 increased. Results shown are mean \pm SD of triplicate cultures. Similar results are obtained in eight other BV-SIT patients. 

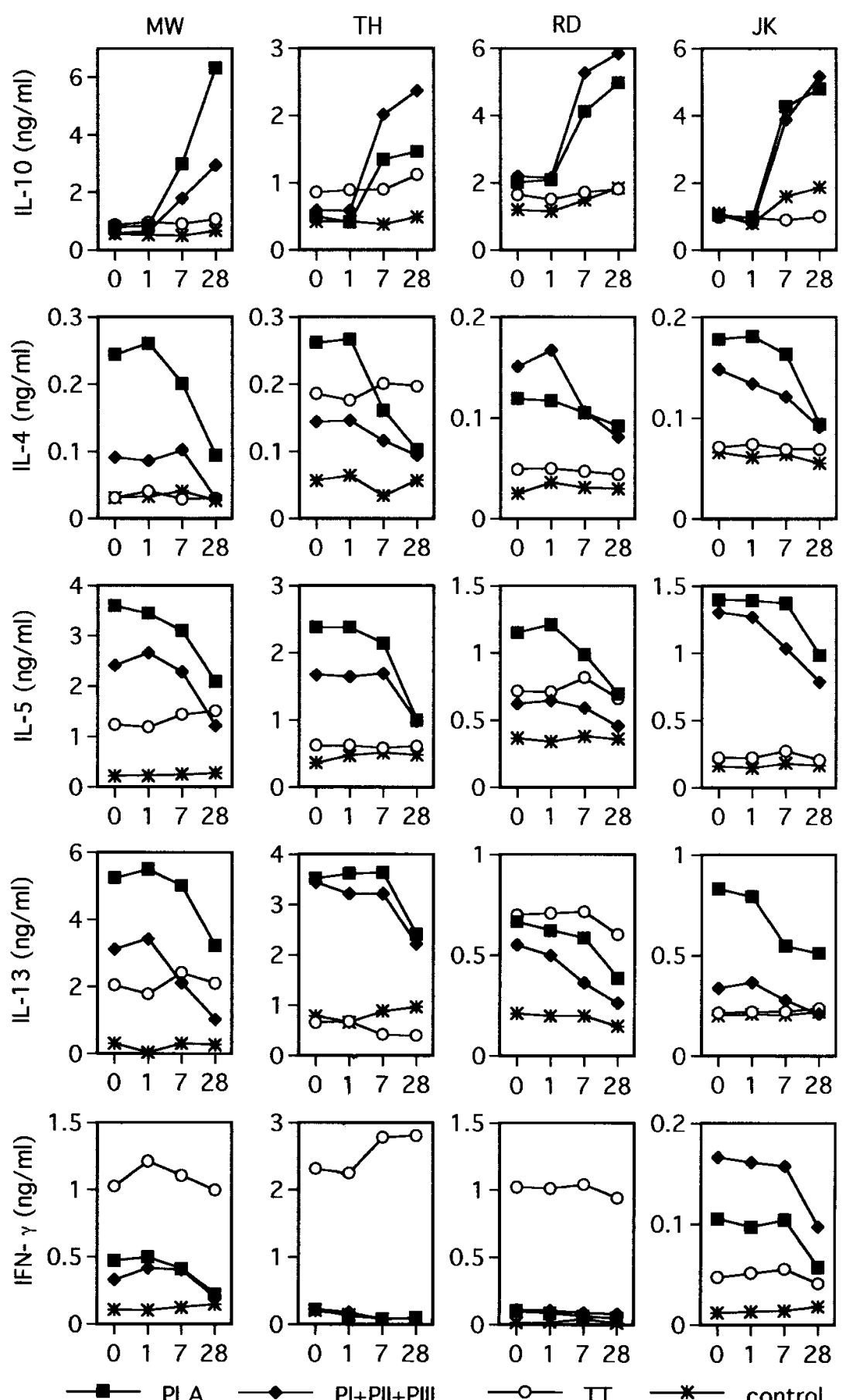

Figure 3. Changes of IL-4, IL-5, IL-10, IL-13, and IFN- $\gamma$ secretion during BV-SIT in response to PLA, PI + PII + PIII mixture, and control Ag (TT). PBMC were stimulated before and after 1 , 7 , and $28 \mathrm{~d}$ of BV-SIT. Cells were expanded in IL-2/IL-4-supplemented cultures, washed, and restimulated with the same antigens in the presence of autologous irradiated PBMC on day 12. Supernatants were harvested after $16 \mathrm{~h}$ for the determination of IL-4 and $48 \mathrm{~h}$ for IL-5, IL-10, IL-13, and IFN- $\gamma$. PLA and PI + PII + PIII-specific IL-4, IL-5, IL-13, and IFN- $\gamma$ production decreased, whereas IL-10 production simultaneously increased. TT induced cytokines did not show any change.

centage of IL-10-containing cells increased from $7.2 \%$ before BV-SIT, to $28.9 \%$ at day 7 , and $44.2 \%$ at day $28(P<0.001)$ (Fig. $4 \mathrm{~A}$ ). Because only a fraction of $\mathrm{CD} 4^{+} \mathrm{CD} 25^{+} \mathrm{T}$ cells is PLA specific, PBMC were stimulated with PLA for $10 \mathrm{~d}$ and intracytoplasmic IL-10 was stained after additional stimulation with anti-CD3 and anti-CD28 mAbs. IL-10-positive PLA-specific $\mathrm{T}$ cells increased from $8.1 \%$ before $\mathrm{BV}$-IT to $43.8 \%$ on day 7 and $49.2 \%$ on day 28 of BV-SIT $(P<0.001)$.

Beside PLA-specific and activated T cells, we have analyzed IL-10 content in monocytes and B cells during BV-SIT. $\mathrm{CD} 14^{+}$monocytes and $\mathrm{CD} 19^{+} \mathrm{B}$ cells were gated and intracy- toplasmic IL-10 was determined immediately after isolation of PBMC. As shown in Fig. $4 \mathrm{~B}$ from the $\mathrm{CD} 14^{+}$stained monocytes only $1.2 \%$ contained intracellular IL-10 before and $3.3 \%$ on day 7 of BV-SIT. After $28 \mathrm{~d}$ of BV-SIT, $41.2 \%$ of the monocyte population was IL-10 positive and showed a full shift in the FACS $^{\circledR}$ histogram $(P<0.001)$. The mean fluorescence intensity of IL-10-positive monocytes increased from 0.713 to 1.520 . From the $\mathrm{CD} 19^{+} \mathrm{B}$ cells $17.9 \%$ showed intracellular IL-10 before and $19.1 \%$ on day 7 of BV-SIT. Similar to monocytes, intracytoplasmic IL-10-containing B cells increased to $41.3 \%$ after $28 \mathrm{~d}$ of BV-SIT $(P<0.001)$. The mean 

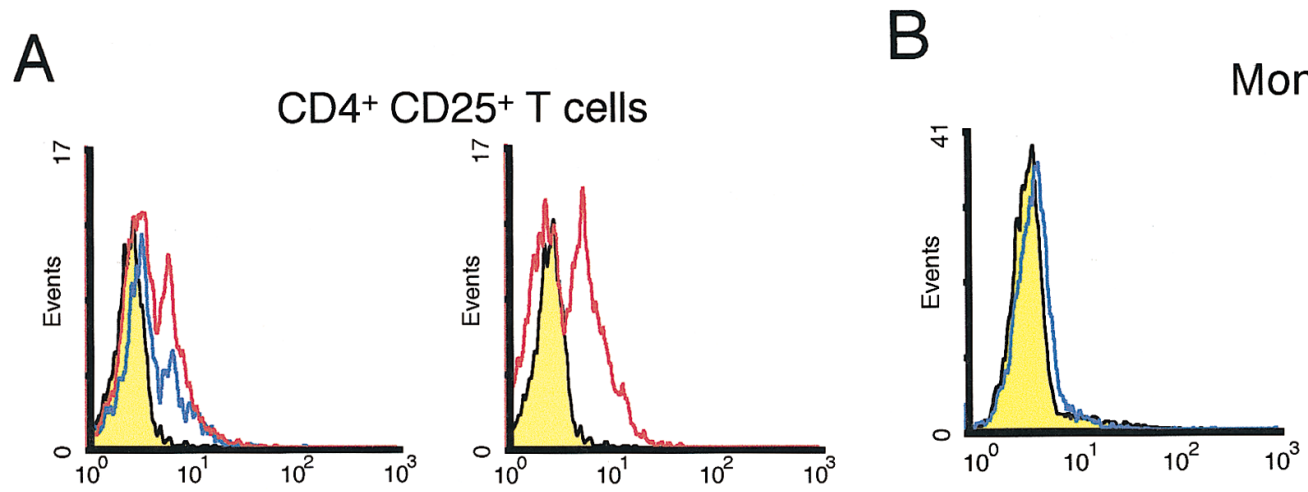

\section{Monocytes}

\section{PLA-specific stimulated T cells}
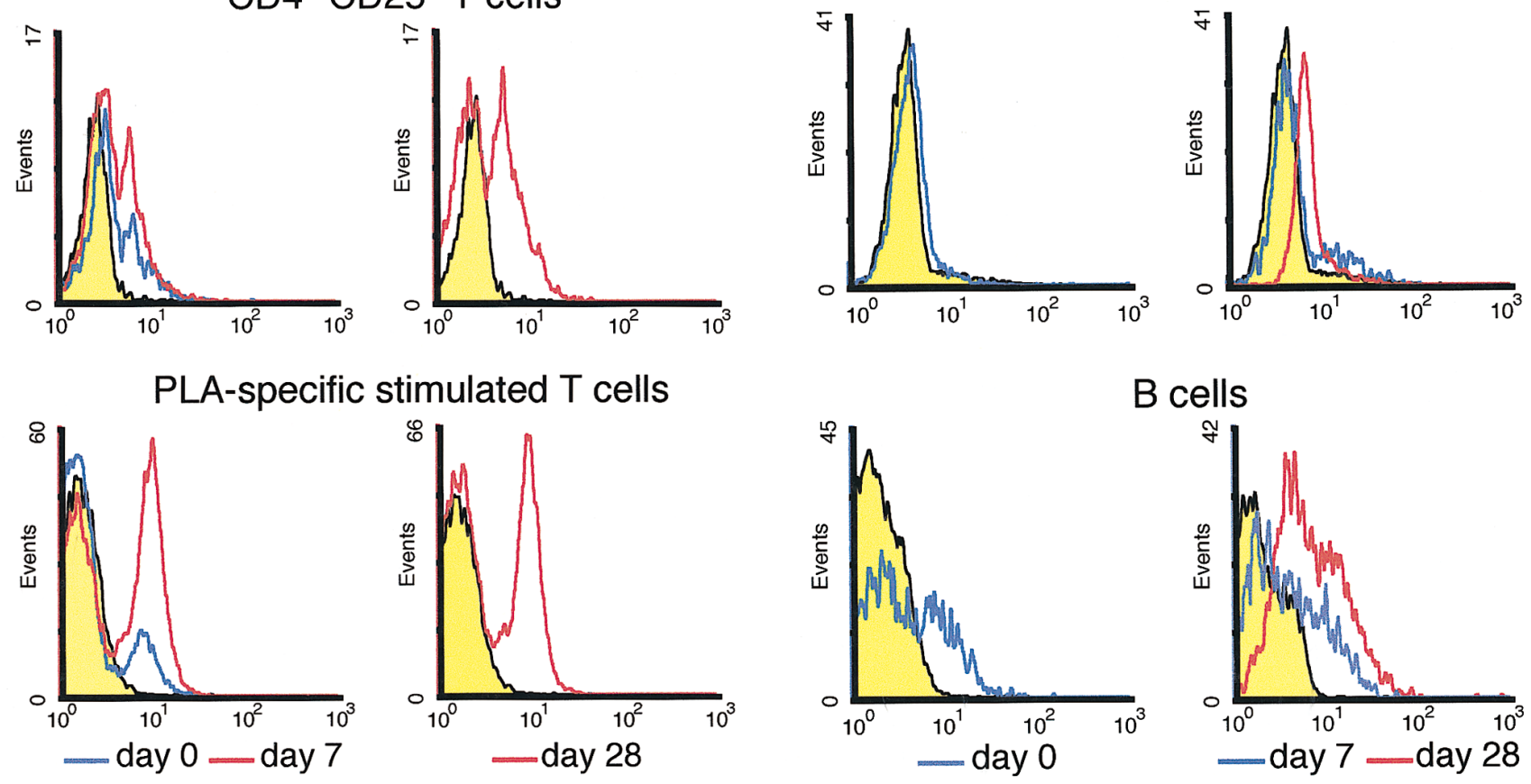

Figure 4. Intracytoplasmic IL-10 content of T cells, monocytes, and B cells during BV-SIT. Immediately after isolation, PBMC were stained for surface markers CD4, CD25, CD14 (monocytes), and CD19 (B cells), then fixed, permeabilized, and counterstained for intracytoplasmic IL-10. (A) Intracytoplasmic IL-10 content in CD ${ }^{+} \mathrm{CD} 25^{+} \mathrm{T}$ cells was significantly increased after $7 \mathrm{~d}$ and continued to increase during $28 \mathrm{~d}$ of BV-SIT. To determine changes in IL-10 content of PLA-specific T cells, PLA-stimulated PBMC were cultured for $10 \mathrm{~d}$ and T cells were restimulated with an anti-CD3/anti-CD28 mixture in the presence of monensin for $5 \mathrm{~h}$. The yellow area represents the isotype control antibody. The IL-10 content of T cells was significantly increased already after $7 \mathrm{~d}$ of BV-SIT. (B) Intracytoplasmic IL-10 content of monocytes and B cells was detected from PBMC. CD $14^{+}$monocytes and CD $19^{+} \mathrm{B}$ cells were gated and intracytoplasmic IL-10 was determined. IL-10 content in monocytes and B cells only increased after $28 \mathrm{~d}$ of BV-SIT. Similar intracytoplasmic IL-10 pattern was obtained in two other BV-SIT patients.

fluorescent intensity of IL-10-containing B cells increased from 0.491 to 1.330

The possibility that these changes in intracytoplasmic IL-10 content in activated $\mathrm{T}$ cells, monocytes, and B cells, could occur spontaneously was ruled out by determination of intracytoplasmic IL-10 in three BV allergic individuals who received no treatment for $28 \mathrm{~d}$. There was no significant change in intracytoplasmic IL-10 content observed in the respective cells of these individuals. The intracytoplasmic IL-10 was detectable in $5.55 \pm 4.07 \%$ of the $\mathrm{CD}^{+} \mathrm{CD} 25^{+} \mathrm{T}$ cells on day 0 and $5.15 \pm 3.28 \%$ after $28 \mathrm{~d}$ without any treatment. $3.12 \pm 2.83 \%$ of the monocytes contained intracytoplasmic IL-10 at day 0 and $3.95 \pm 2.52 \%$ after 28 d. $13.47 \pm 4.78 \%$ of the B cells contained intracytoplasmic IL-10 at day 0 and $14.87 \pm 4.91 \%$ after $28 \mathrm{~d}$.

Anergized specific $T$ cell response in BV-SIT can be reestablished by neutralization of endogenous IL-10 in cultures. Because the specific T cell anergy in BV-SIT was associated with increased IL-10 production, we investigated whether specific responses of in vivo anergized $\mathrm{T}$ cells can be restored by IL-10 neutralization in vitro. For this purpose PBMC were cultured with PLA or PLA peptides in the presence or absence of neutralizing anti-IL-10 mAb. As shown in Fig. $5 \mathrm{~A}$, without anti-IL-10 addition, the PLA and PLA peptide-specific proliferative responses started to decrease after $7 \mathrm{~d}$ of BV-SIT and reached their lowest values after $28 \mathrm{~d}$. With IL-10 neutralization, the abrogated specific T cell proliferation (Fig. $5 \mathrm{~A}$ ) and production of both Th1 (IFN- $\gamma$ ) and Th2 (IL-4, IL-5, IL-13) cytokines (Fig. $5 \mathrm{~B}$ ) were fully reestablished, indicating that IL-10 is actively involved in the generation of anergy in PLAspecific T cells. Due to neutralization of IL-10, the proliferative responses to PLA and PLA peptides, but also to TT, were slightly higher than without $\mathrm{mAb}$ treatment, but remained at this level throughout.

IL-10 inhibits the production of allergen-specific and total IgE and enhances IgG4 in vitro. Although knowledge of the molecular and cellular basis of human IgE antibody regulation has increased during recent years, the entire mechanism controlling allergen-specific IgE and IgG4 production needs further elucidation. For this purpose, a PBMC-based cell culture system has been established (5). This procedure, which was already successfully applied for studies of drug-induced IgE regulation (39), allows the in vitro generation of human allergenspecific IgE antibodies. PBMC from BV allergic subjects were specifically stimulated with allergen and polyclonally with sCD40L, in the presence of IL-4. As demonstrated in Fig. $6 \mathrm{~A}$, addition of IL-10 to the culture exerted clear counterregulatory effects on both the PLA-specific and total IgE and IgG4 synthesis by inhibiting IgE and enhancing IgG4 antibodies in a 
A

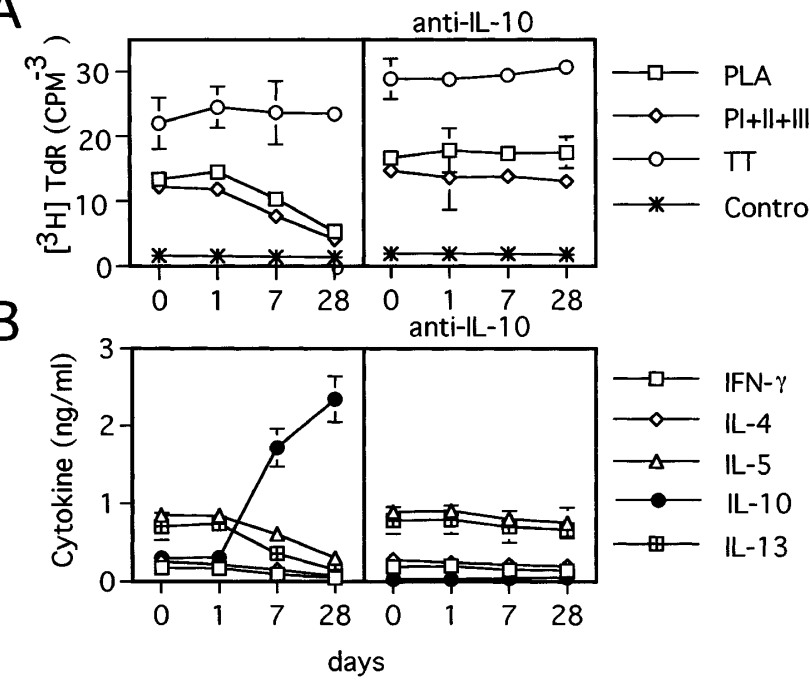

Figure 5. T cell proliferation and cytokine response was not suppressed in IL-10-neutralized PBMC cultures of a BV-SIT patient. PBMC were stimulated with PLA, the PLA peptides PI + PII + PIII, or with TT control antigen, with and without neutralizing anti-IL-10 antibodies before and after 1, 7, and $28 \mathrm{~d}$ of BV-SIT. [ $\left.{ }^{3} \mathrm{H}\right]$ Thymidine incorporation was measured after $7 \mathrm{~d}$. Cells were expanded in IL-2and IL-4-supplemented cultures for $7 \mathrm{~d}$, then washed, and restimulated with the same antigen in the presence of autologous irradiated PBMC at day 12. Abolished PLA and PLA peptide-specific $(A)$ proliferative and $(B)$ cytokine responses were reconstituted by neutralization of endogenously produced IL-10. Results shown are mean \pm SD of triplicate cultures. Same results were obtained from two other BV-SIT patients.

dose-dependent manner. To analyze whether this was a direct effect on B cells, purified B cells from PBMC were stimulated in the presence or absence of IL-10, using the same culture system as described above. As shown in Fig. $6 \mathrm{~B}$, IL-10 inhibited the total IgE synthesis by $84 \%$ and simultaneously enhanced IgG4 up to 4.5 times. The $\mathrm{IgE} / \mathrm{IgG} 4$ ratio changed on average from $\sim 0.5$ to 0.01 , by a factor of 50 in favor of IgG4. Accordingly, IL-10 acts not only on T cells but also directly on Ig isotype synthesis by $\mathrm{B}$ cells.

IL-10 induced natural $T$ cell tolerance in hyperimmune individuals after exposure to bee stings. It is generally observed that hyperimmune individuals (beekeepers) after multiple bee stings develop a state of low responsiveness to BV allergen. As shown in Fig. $7 A$, PBMC from such persons, who were previously stung more often ( $>20$ times), showed abolished PLAspecific proliferative and IL-5 and IFN- $\gamma$ cytokine responses. This state of specific anergy corresponds to that observed in patients after BV-SIT, and similar high levels of IL-10 were found after PLA-specific stimulation. IL-4 and IL-13 were not detectable. Specific stimulation in the presence of neutralizing anti-IL-10 resulted in enhanced PLA-specific proliferation and IL-5 and IFN- $\gamma$ production. Also, in these beekeepers who are hyperimmune to PLA, the intracytoplasmic IL-10 content of activated $\mathrm{T}$ cells and monocytes was analyzed directly from PBMC. Again, similar to patients after $28 \mathrm{~d}$ of BV-SIT, activated $\mathrm{T}$ cells and monocytes expressed high intracytoplasmic IL-10 contents and no IFN- $\gamma$ (Fig. 7 B).

\section{Discussion}

Recently, we demonstrated that BV-SIT induces a state of epitope-specific anergy in T cells against PLA, the major allergen of BV (30). The anergy, which could also be generated in $\mathrm{T}$ cell clones after peptide-ligand activation in the absence of accessory signals (40), was characterized by suppressed proliferative and cytokine responses. Circulating anergic $\mathrm{T}$ cells from peripheral blood could be reactivated to produce Th1 cytokines by culturing the cells with IL-2 or IL-15 (30). The presented data indicate that the specific anergic state in $\mathrm{T}$ cells was induced by IL-10, initially produced by the specific peripheral $\mathrm{T}$ cells themselves after high-dose allergen administration during BV-SIT. The IL-10 production in epitope-specific T cells was already significantly enhanced after $7 \mathrm{~d}$ of SIT, while simultaneously the specific proliferative and cytokine responses were decreasing. This was confirmed by demonstrating increased intracytoplasmic IL-10 content in the activated $\mathrm{CD} 25^{+} \mathrm{CD} 4^{+} \mathrm{T}$ cell subset. In contrast, the synthesis of IL-10 in $\mathrm{B}$ cells and monocytes did not change until BV-SIT was prolonged for $1 \mathrm{mo}$. Probably while the anergic state in activated T cells progressed during BV-SIT, IL-10 production in these cells influenced the antigen-presenting cells (APC) and shifted to B cells and monocytes.

It appears from the multicolor FACS ${ }^{\circledR}$ analyses that in BVSIT IL-10 production is initially triggered in Ag-specific T cells, followed by the APC population and activated BV nonspecific bystander T cells. IL-10 plays an important role in both induction and maintenance of specific $\mathrm{T}$ cell tolerance

A
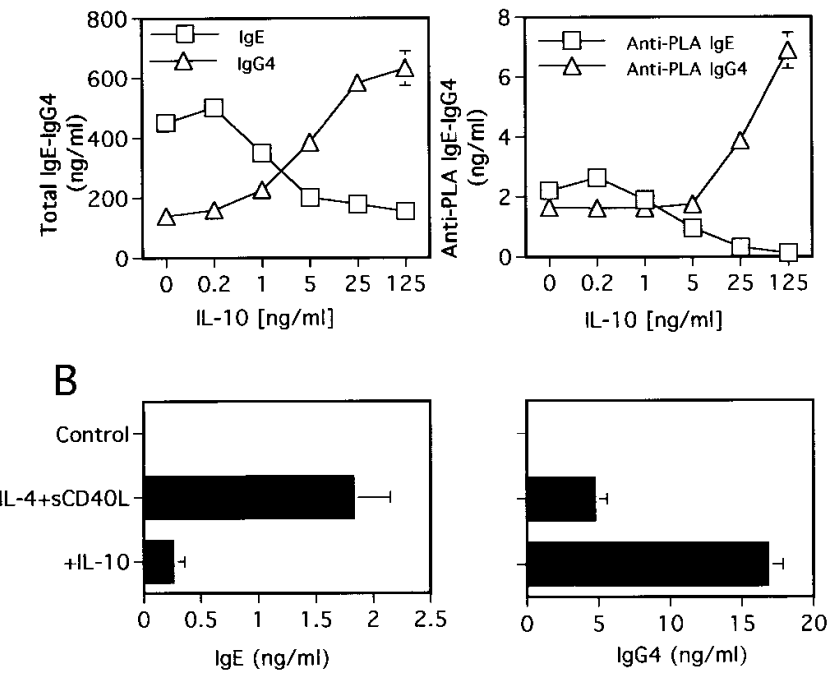

Figure 6. IL-10 counterregulates total and PLA-specific IgE and IgG4 synthesis. ( $A$ ) PBMC were stimulated with PLA, in the presence of IL-4 and SCD40L and different amounts of IL-10. PLA-specific and total $\operatorname{IgE}$ and $\operatorname{IgG} 4$ were determined in supernatants from 12-d cultures. (B) Isotype synthesis in purified B cells stimulated with IL-4 and SCD40L with and without IL-10. In both PBMC and B cell cultures IL-10 exerted counterregulatory effects by inhibiting IgE and enhancing IgG4 formation. The results shown are mean \pm SD of triplicate cultures, representative of two BV allergic and two healthy hyperimmune individuals with the same results. 
A

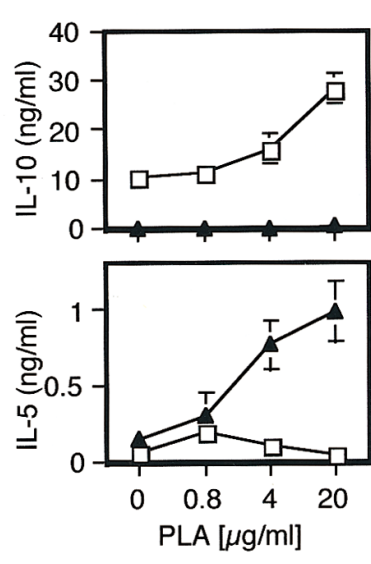

$\square-\mathrm{PBMC}$

B

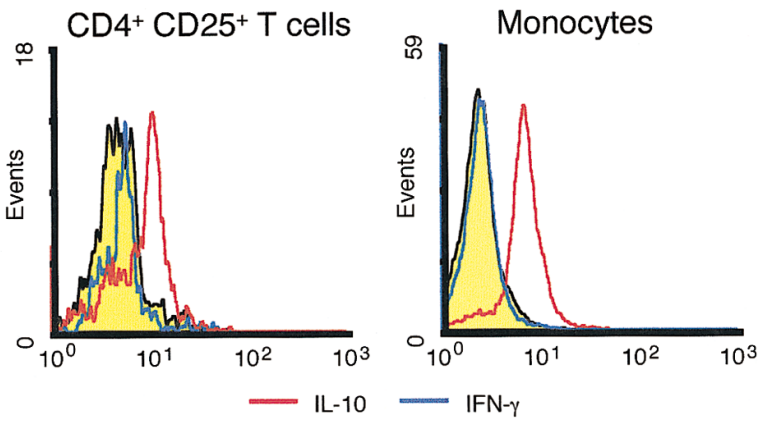

Figure 7. Natural tolerance to PLA in hyperimmune subjects repeatedly stung by honey bees resembles the same features as BV-SIT of allergic patients and is induced by IL-10. (A) PBMC from hyperimmune individuals, who were exposed to $>20$ honey bee stings during the last $2 \mathrm{mo}$, were stimulated with different amounts of PLA. The $\left[{ }^{3} \mathrm{H}\right]$ thymidine incorporation was measured after $7 \mathrm{~d}$ and cytokines were determined in culture supernatants after $5 \mathrm{~d}$. Neutralization of endogenous IL-10 fully reconstituted the proliferative and cytokine responses in anergic cells. The results shown are mean \pm SD of triplicate cultures from two hyperimmune individuals. Decreased PLAspecific $\mathrm{T}$ cell proliferation in beekeepers after beekeeping season is observed in seven experiments. (B) High intracytoplasmic IL-10 but no IFN- $\gamma$ was found in $\mathrm{CD} 4{ }^{+} \mathrm{CD} 25^{+}$cells and monocytes of naturally anergized subjects. The yellow area represents the isotype control $\mathrm{Ab}$. Same results were obtained from two beekeepers.

(41-43). Therefore, high IL-10 secretion by antigen-presenting $B$ cells and monocytes may potentiate and maintain anergy in the specific $\mathrm{T}$ cells. Interestingly, the same features of anergy were found in $\mathrm{T}$ cells of both patients after BV-SIT and healthy hyperimmune subjects, which had been stung repeatedly by honey bees. These naturally anergized individuals showed similar high numbers of IL-10-containing $\mathrm{CD} 4{ }^{+} \mathrm{CD} 25^{+} \mathrm{T}$ cells as treated allergic patients after BV-SIT. This indicates a pivotal role of IL-10 in naturally induced T cell anergy as well. In mice, IL-10 administration before allergen treatment induces antigen-specific tolerance (41). Inhibition of graft versus host disease and allograft rejection by IL-10 in HLA-mismatched, bone marrow-transplanted, severe combined immunodeficiency patients gives strong evidence for pe- ripheral tolerance induction and maintenance by this cytokine (42). Similarly, inadequate stimulation of tumor reactive human T cells was shown to result from increased endogenous IL-10 production by these cells, also indicating a role for IL-10 in tumor specific anergy (43). Induction of specific anergy in mice and humans requires high amounts of antigen or $\mathrm{T}$ cell epitope peptides applied by oral or subcutaneous routes (44, 45). The amount of BV given in rush BV-SIT in the first week $(200 \mu \mathrm{g})$ is about four times higher than the dose received by a single bee sting (46). This may lead to increased IL-10 production and induction of peripheral anergy in specific $\mathrm{T}$ cells. Recently, a regulatory $\mathrm{T}$ cell subset, producing high IL-10 and suppressing antigen-specific responses was identified in both humans and mice (47). The IL-10-dominated cytokine pattern and anergy-inducing function of these cells appear to be similar to those observed in BV-SIT patients and naturally hyperimmunized individuals. These results suggest that the increase of IL-10 content in APC may not represent the only factor involved in inhibition of antigen-specific responses. Apparently, the change in cytokine pattern of T cells to IL-10-producing T cells may be more pertinent and of greater importance because only PLA-specific T cells secrete increased IL-10 but not TT-specific T cells. Thus, there is no TT-specific anergy during BV-SIT.

There is a discrepancy in cytokine changes during SIT (26, 27, 29, 30). Different reasons could be considered for this inconsistency. BV allergics are usually monoallergic in comparison to polyallergic and atopic hay fever patients. The protocols of the immunotherapies differ in these studies: in ultra-rush immunotherapy a high dose is given in the first day which is much more than the amount received in classical immunotherapy. Finally, the methodological differences in restimulation of $T$ cells by anti-CD3 instead of antigen-specific stimulation may be responsible for differences in cytokine production (27).

IL-10 was originally described as a mouse Th2 cell factor, inhibiting cytokine synthesis by Th1 cells (48). However, neutralization of IL-10 in PBMC cultures reconstituted both type 1 and type 2 cytokine production and proliferative response. Indeed, increasing evidence accumulated that IL-10 also acts as an inhibitor of Th2 cell responses both in vitro and in vivo $(10,12,48-50)$. In particular, IL-10 was found to downregulate IL-5 production by human resting $\mathrm{T}$ cells and in human Th0 and Th2 clones $(12,50)$. The inhibitory action of IL-10 on IL-5 synthesis was confirmed in a murine model of allergic eosinophilic peritonitis and airway eosinophilia in which IL-10 administration suppressed both IL-5 production and eosinophil recruitment $(49,50)$. In addition, IL-10 inhibited endogenous GM-CSF production and CD40 expression by activated eosinophils and enhanced eosinophil death $(51,52)$. The inhibitory effect of IL-10 in T cell clones was observed only in APC-dependent systems, and not in solid-phase anti-CD3 stimulated T cells $(9,49,50,53)$. The reason for this may be that IL-10 blocks CD28/B7.1 interaction and subsequent costimulatory signaling pathways (12). The absence of accessory molecule signaling may thus explain peptide ligand-induced specific anergy in pure T cell systems (40).

As previously demonstrated, B cells were not affected by BV-SIT and were still able to produce specific antibodies (26, 30). In consequence, both IgE and IgG4 anti-PLA antibodies are normally raised during the first 2 mo of BV-SIT but change the PLA-specific $\operatorname{IgE} / \operatorname{IgG} 4$ ratio in favor of $\operatorname{IgG} 4(15,17,18$, $30)$. IL-10 is a potent suppressor of IgE production in IL-4- 
stimulated PBMC (54) and, as we have shown, of specific $\operatorname{IgE}$ in IL-4/sCD40L-stimulated cultures, while simultaneously increasing IgG4 formation. In this way IL-10 appears to participate in the counterregulatory mechanisms of antigen-specific $\mathrm{IgE}$ and $\mathrm{IgG} 4$ synthesis by memory B cells.

Although definite decreases in $\operatorname{IgE}$ antibody synthesis and IgE-mediated skin sensitivity require 6-12 mo of treatment $(55,56)$, most patients are protected when restung by a bee during the first months of BV-SIT. The protective effect of the SIT may primarily originate from the suppression of cytokine and mediator release from mast cells and basophils. IL-10 was shown to reduce TNF- $\alpha$, GM-CSF, and IL-6 generation from mouse bone marrow and rat peritoneal mast cells in response to specific IgE cross-linking $(57,58)$. Recent studies indicate that mast cells may represent important targets of IL-10 during $\mathrm{BV}$-SIT, and it was shown that histamine and sulfidoleukotriens release from PLA-stimulated blood basophils is already greatly reduced at the very early phase of BV-SIT (59). The mechanism of this decrease in basophil releasability may be associated with anergy induction in T cells, since effector cells in allergy require priming by $\mathrm{T}$ cell cytokines for full activity and mediator release $(60,61)$.

The results of this study provide additional insight into the physiological mechanisms of SIT. Administration of high allergen doses, as applied in immunotherapy, enhances endogenous production of IL-10, first in specific T cells and later in APC. This results in specific T cell anergy and selective counterregulation of antigen-specific $\operatorname{IgE}$ and $\operatorname{IgG} 4$ by B cells in favor of IgG4. In consequence, increased IL-10 synthesis in allergic inflammation may also inhibit effector cells of allergy. Anergized $\mathrm{T}$ cells can be reactivated by cytokines produced in the microenvironment that can govern the secondary induction of distinct Th1 or Th2 cytokine patterns associated with either normal immunity against an allergen or with further development of allergy and inflammation (30). In this state of immune response it was shown that high antigen doses also generate Th0 cytokine patterns in newly activated $\mathrm{T}$ cells, which is required for eliciting a protective IgG4 response (62).

\section{Acknowledgments}

We are grateful to Dr. Jan De Vries (DNAX Research Institute, Dept. of Human Immunology) for anti-IL-13 mAb and Dr. Christoph H. Heusser and Dr. Sefik S. Alkan for anti-IL-4 and anti-IFN- $\gamma$ mAbs.

This work was sponsored by the Swiss National Foundation (grant no. 31.39.177.93).

\section{References}

1. Del Prete, G., E. Maggi, P. Paola, I. Ghretien, A. Tiri, D. Macchia, J. Banchereau, J.E. De Vries, and S. Romagnani. 1988. IL-4 is an essential factor for the $\mathrm{IgE}$ synthesis induced in vitro by human $\mathrm{T}$ cell clones and their supernatants. J. Immunol. 140:4193-4198.

2. Punnonen, J., G. Aversa, B.G. Cocks, A.N.J. McKenzie, S. Menon, G. Zurawski, R. De Waal Malefyt, and J.E. De Vries. 1993. Interleukin-13 induces interleukin-4 independent IgG4 and IgE synthesis and CD23 expression by human B cells. Proc. Natl. Acad. Sci. USA. 90:3730-3734.

3. Walker, C., J.C. Virchow, Jr., P.L.B. Bruijnzeel, and K. Blaser. 1991. T cell subsets and their soluble products regulate eosinophilia in allergic and nonallergic asthma. J. Immunol. 146:1829-1835.

4. Aalberse, R.C., R. van der Gaag, and J. van Leuwen. 1983. Serologic aspects of IgG4 antibodies. I. Prolonged immunization results in an IgG4restricted response. J. Immunol. 130:722-726.

5. Akdis, C.A., T. Blesken, M. Akdis, S.S. Alkan, B. Wüthrich, C.H.
Heusser, and K. Blaser. 1997. Induction and differential regulation of bee venom phospholipase $\mathrm{A}_{2}$-specific human $\mathrm{IgE}$ and $\mathrm{IgG} 4$ antibodies in vitro requires allergen-specific and nonspecific activation of T and B cells. J. Allergy Clin. Immunol. 99:345-353.

6. Carballido, J.M., N. Carballido-Perrig, A. Oberli-Schrämmli, C.H. Heusser, and K. Blaser. 1994. Regulation of IgE and IgG4 responses by allergen-specific T-cell clones to bee venom phospholipase $\mathrm{A}_{2}$ in vitro. J. Allergy Clin. Immunol. 93:758-767.

7. Akdis, M., C.A. Akdis, L. Weigl, R. Disch, and K. Blaser. 1997. Skin homing, $\mathrm{CLA}^{+}$memory $\mathrm{T}$ cells are activated in atopic dermatitis and regulate IgE by IL-13 dominated cytokine pattern. IgG4 counter-regulation by CLA memory T cells. J. Immunol. 159:4611-4619.

8. Fiorentino, D.F., A. Zlotnik, T.R. Mosmann, M. Howard, and A. O'Garra. 1991. IL-10 inhibits cytokine production by activated macrophages. $J$. Immunol. 147:3815-3822.

9. De Waal Malefyt, R., J. Abrams, B. Bennett, C.G. Figdor, and J.E. De Vries. 1991. Interleukin 10 (IL-10) inhibits cytokine synthesis by human monocytes: an autoregulatory role of IL-10 produced by monocytes. J. Exp. Med. 174:1209-1220.

10. Hsu, D.-H., K.W. Moore, and H. Spits. 1992. Differential effects of interleukin- 4 and -10 on interleukin- 2 induced interferon- $\gamma$ synthesis and lymphokine activated killer activity. Int. Immunol. 4:563-569.

11. Del Prete, G., M. DeCarli, F. Almerigogna, M.G. Giudizi, R. Biagiotti, and S. Romagnani. 1993. Human IL-10 is produced by both type 1 helper (Th1) and type 2 helper (Th2) T cell clones and inhibits their antigen-specific proliferation and cytokine production. J. Immunol. 150:353-360.

12. Schandene, L., C. Alonso-Vega, F. Willems, C. Gerard, A. Delvaux, T. Velu, R. Devos, M. de Boer, and M. Goldman. 1994. B7/CD28-dependent IL-5 production by human resting $\mathrm{T}$ cells is inhibited by IL-10. J. Immunol. 152: 4368-4374.

13. Kagey-Sabotka, A., R.M. Franklin, N.F. Adkinson, Jr., M. Valentine, H. Bauer, and L.M. Lichtenstein. 1976. Allergy to insect sting. II. Phospholipase A: the major allergen in honey bee venom. J. Allergy Clin. Immunol. 57:29-40.

14. Müller, U.R., T. Dudler, T. Schneider, R. Crameri, H. Fischer, D. Skrbic, R. Maibach, K. Blaser, and M. Suter. 1995. Type 1 skin reactivity to native and recombinant phospholipase $\mathrm{A}_{2}$ from honey bee venom is similar. $\mathrm{J}$. Allergy Clin. Immunol. 96:395-402.

15. Carballido, J.M., N. Carballido-Perrig, M.K. Kägi, R.H. Meloen, B. Wüthrich, C.H. Heusser, and K. Blaser. 1993. T cell epitope specificity in human allergic and non-allergic subjects to bee venom phospholipase $\mathrm{A}_{2}$. J. Immunol. 150:3582-3591.

16. Lucas, A.H. 1990. IgG subclass restricted immune responses to allergens. Semin. Immunopathol. 12:385-420.

17. Randolph, C.C., and R.E. Reismann. 1986. Evaluation of decline in serum venom specific IgE as a criterion for stopping venom immunotherapy. $J$. Allergy Clin. Immunol. 77:823-827.

18. Wyss, M., T. Scheitlin, B.M. Stadler, and B. Wüthrich. 1993. Immunotherapy with aluminum hydroxide adsorbed insect venom extracts (Alutard SQ): immunologic and clinical results of a prospective study over 3 years. $A l$ lergy. 48:81-86.

19. Reid, M.J., R.B. Moss, Y.P. Hsu, J.M. Kwasnicki, T.M. Commerford, and B.L. Nelson. 1986. Seasonal asthma in northern California: allergic causes and efficacy of immunotherapy. J. Allergy Clin. Immunol. 78:590-600.

20. Hussain, R., R.W. Poindexter, and E.A. Ottesen. 1992. Control of allergic reactivity in human filariasis. Predominant localization of blocking antibodies to the IgG4 subclass. J. Immunol. 148:2731-2739.

21. Rocklin, R.E., A. Sheffer, D.K. Greineder, and K.L. Melmon. 1980. Generation of antigen-specific suppressor cells during allergy desensitization. N. Engl. J. Med. 302:1213-1219.

22. Otsuka, H., A. Mezawa, M. Ohnishi, K. Okubo, H. Seki, and M. Okuda. 1991. Changes in nasal metachromatic cells during allergen immunotherapy. Clin. Exp. Allergy. 21:115-120.

23. Crecitos, P.S., N. Franklin Adkinson, Jr., A. Kagey-Sobotka, D. Proud, H.L. Meier, R.M. Naclerio, L.M. Lichtenstein, and P.S. Norman. 1983. Nasal challenge with ragweed in hay fever patients. Effect of immunotherapy. J. Clin. Invest. 76:2247-2253.

24. Furin, M.J., P.S. Norman, P.S. Creticos, D. Proud, A. Kagey-Sobotka, L.M. Lichtenstein, and R.M. Naclerio. 1991. Immunotherapy decreases antigen-induced eosinophil migration into the nasal cavity. J. Allergy Clin. Immunol. $88: 27-32$.

25. Rak, S., O. Rowhagen, and P. Venge. 1988. The effect of immunotherapy on bronchial hyper-responsiveness and eosinophil cationic protein in pollen allergic patients. J. Allergy Clin. Immunol. 82:470-480.

26. Secrist, H. C.J. Chelen, Y. Wen, J.D. Marshall, and D.T. Umetsu. 1993. Allergen immunotherapy decreases interleukin 4 production in CD4 T cells from allergic individuals. J. Exp. Med. 178:2123-2130.

27. Jutel, M., W.J. Pichler, D. Skrbic, A. Urwyler, C. Dahinden, and U.R Müller. 1995. Bee venom immunotherapy results in decrease of IL-4 and IL-5 and increase of IFN- $\gamma$ secretion in specific allergen stimulated T cell cultures. $J$. Immunol. 154:4187-4194.

28. Secrist, H., R.H. DeKruyff, and D.T. Umetsu. 1995. Interleukin 4 production by $\mathrm{CD}^{+} \mathrm{T}$ cells from allergic individuals is modulated by antigen con- 
centration and antigen-presenting cell type. J. Exp. Med. 181:1081-1089.

29. Bellinghousen, I., G. Metz, A.H. Enk, S. Christmann, J. Knop, and J. Saloga. 1997. Insect venom immunotherapy induces interleukin-10 production and a Th2-to-Th1 shift, and changes surface marker expression in venom-allergic subjects. Eur. J. Immunol. 27:1131-1139.

30. Akdis, A.C., M. Akdis, T. Blesken, D. Wymann, S.S. Alkan, and K. Blaser. 1996. Epitope specific $\mathrm{T}$ cell tolerance to phospholipase $\mathrm{A}_{2}$ in bee venom immunotherapy and recovery by IL-2 and IL-15 in vitro. J. Clin. Invest. 98: 1676-1683.

31. Mueller, H.L. 1966. Diagnosis and treatment of insect sensitivity. $J$. Asthma Res. 3:331-333.

32. Birnbaum, J., D. Charpin, and D. Vervloet. 1993. Rapid hymenoptera venom immuno-therapy: comparative safety of three protocols. Clin. Exp. Allergy. 23:226-230.

33. Von Grüningen, R., and C.H. Schneider. 1989. Antigenic structure of the hexacosa-peptide mellitin: evidence for three determinants, one with a helical conformation. Immunology. 66:339-342.

34. Lane, P., T. Brocker, S. Hubele, E. Padovan, A. Lanzavecchia, and F.F. McConnell. 1993. Soluble CD40 ligand can replace the normal T cell derived CD40 ligand signal to B cells in T cell-dependent activation. J. Exp. Med. 177: 1209-1213.

35. Gascan, H., J.-F. Gauchat, G. Aversa, P. Van Vlasselaer, and J.E. De Vries. 1991. Anti-CD40 monoclonal antibodies or CD4 ${ }^{+} \mathrm{T}$ cell clones and IL-4 induce IgG4 and IgE switching in purified B cells via different signaling pathways. J. Immunol. 147:8-13.

36. Prussin, C., and D. Metcalfe. 1995. Detection of intracytoplasmic cytokine using flow cytometry and directly conjugated anti-cytokine antibodies. $J$. Immunol. Methods. 188:117-125.

37. Miltenyi, S., W. Muller, W. Weichel, and A. Radbruch. 1990. A high gradient magnetic cell separation with MACS. Cytometry. 11:231-238.

38. Schneider, T., A.B. Lang, J.M. Carballido, L.F. Santamaria Babi, T. Dudler, M.K. Kägi, K. Blaser, and M. Suter. 1994. Human monoclonal and polyclonal antibodies recognize predominantly discontinuous epitopes on bee venom phospholipase A. J. Allergy Clin. Immunol. 94:61-69.

39. Akdis, C.A., T. Blesken, M. Akdis, S.S. Alkan, C.H. Heusser, and K. Blaser. 1997. Glucocorticoids inhibit human antigen-specific and enhance total $\mathrm{IgE}$ and IgG4 production due to differential effects on $\mathrm{T}$ and $\mathrm{B}$ cells in vitro. Eur. J. Immunol. 27:2351-2357.

40. Faith, A., C.A. Akdis, M. Akdis, H.-U. Simon, and K. Blaser. 1997. Defective TCR stimulation in anergized type $2 \mathrm{~T}$ helper cells correlates with abrogated $\mathrm{p} 56^{\mathrm{lck}}$ and Zap 70 tyrosine kinase activities. J. Immunol. 159:53-60.

41. Enk, A.H., J. Saloga, D. Becker, M. Mohamadzadeh, and J. Knop. 1994. Induction of hapten-specific tolerance by interleukin 10 in vivo. J. Exp. Med. 179:1397-1402.

42. Bacetta, R., M. Bigler, J.-L. Touraine, R. Parkman, P.-A. Tovo, J. Abrams, R. de Waal Malefyt, J.E. De Vries, and M.G. Roncarolo. 1994. High levels of interleukin 10 production in vivo are associated with tolerance in SCID patients transplanted with HLA mismatched hematopoietic stem cells. $J$. Exp. Med. 179:493-502.

43. Becker, J.C., C. Czerny, and E.-B. Bröcker. 1994. Maintenance of clonal anergy by endogenously produced IL-10. Int. Immunol. 6:1605-1612.

44. Müller, U., C.A. Akdis, M. Fricker, M. Akdis, T. Blesken, F. Bettens, and K. Blaser. 1998. Successful immunotherapy with T-cell epitope peptides of bee venom phospholipase $A_{2}$ induces specific T-cell anergy in patients allergic to bee venom. J. Allergy Clin. Immunol. In press.

45. Hoyne, G.F., R.E. O'Hehir, D.C. Wraith, W.R. Thomas, and J.R. Lamb. 1993. Inhibition of $\mathrm{T}$ cell and antibody responses to house dust mite allergen by inhalation of the dominant $\mathrm{T}$ cell epitope in naive and sensitized mice. J. Exp. Med. 178:1783-1788.

46. Lichtenstein, L.M., M.D. Valentine, and A. Kagey-Sobotka. 1974. A case for venom treatment in anaphylactic sensitivity to hymenoptera sting. $N$. Engl. J. Med. 290:1223-1227.

47. Groux, H., A. O'Garra, M. Bigler, M. Rouleau, S. Antonenko, J.E. De Vries, and M.G. Roncarolo. 1997. A CD4 ${ }^{+}$T-cell subset inhibits antigen-specific T cell responses and prevents colitis. Nature. 389:737-742.

48. Fiorentino, D.F., M.W. Bond, and T.R. Mosmann. 1989. Two types of mouse T helper cell IV. Th2 clones secrete a factor that inhibits cytokine production by Th1 clones. J. Exp. Med. 170:2081-2095.

49. Zuany-Amorim, C., S. Hailé, D. Leduc, C. Dumarey, M. Huerre, B.B Vergaftig, and M. Pretolani. 1995. Interleukin 10 inhibits antigen-induced cellular recruitment into the airways of sensitized mice. J. Clin. Invest. 95:2644-2651.

50. Zuany-Amorim, C. C. Creminon, M.C. Nevers, M-A. Nahori, B.B. Vergaftig, and M. Pretolani. 1996. Modulation by IL-10 of antigen-induced IL-5 generation, and $\mathrm{CD}_{4}^{+} \mathrm{T}$ lymphocyte and eosinophil infiltration into the mouse peritoneal cavity. J. Immunol. 157:377-384.

51. Takanaski, S., R. Nonaka, Z. Xing, P. O'Byrne, J. Dolovich, and M. Jordana. 1994. Interleukin 10 inhibits lipopolysaccharide-induced survival and cytokine production by human peripheral blood eosinophils. J. Exp. Med. 180: 711-715.

52. Ohkawara, Y., K.G. Lim, M. Glibetic, K. Nakano, J. Dolovich, K. Croitoru, P.F. Weller, and M. Jordana. 1996. CD40 expression by human peripheral blood eosinophils. J. Clin Invest. 97:1761-1766.

53. Ding, L., and E.M. Shevach. 1992. IL-10 inhibits mitogen-induced T cell proliferation by selectively inhibiting macrophage co-stimulatory function. $J$. Immunol. 148:3133-3139.

54. Punnonen, J.R., R. de Waal Malefyt, P. van Vlasselaer, J.-F. Gauchat, and J.E. De Vries. 1993. IL-10 and viral IL-10 prevent IL-4-induced IgE synthesis by inhibiting the accessory cell function of monocytes. J. Immunol. 151: $1280-1289$.

55. Müller, U., and H. Mosbech. 1993. Position paper: immunotherapy with hymenoptera venoms. Allergy. 48(Suppl. 14):36-46.

56. Hunt, K., M. Valentine, A. Sobotka, A. Benton, F. Amoido, and L. Lichtenstein. 1978. A controlled trial of immunotherapy in insect hypersensitivity N. Engl. J. Med. 299:157-161.

57. Arock, M., C. Zuany-Amorim, M. Singer, M. Benhamou, and M. Pretolani. 1996. Interleukin-10 inhibits cytokine generation from mast cells. Eur. J. Immunol. 26:166-170.

58. Marshall, J.S., I. Leal-Berumen, L. Nielsen, M. Glibetic, and M. Jordana. 1996. Interleukin (IL)-10 inhibits long-term IL-6 production but not preformed mediator release from rat peritoneal mast cells. J. Clin. Invest. 97:11221128.

59. Jutel, M., U. Müller, M. Fricker, S. Rihs, W. Pichler, and C. Dahinden. 1996. Influence of bee venom immunotherapy on degranulation and leukotriene generation in human blood basophils. Clin. Exp. Allergy. 26:1112-1118.

60. Schleimer, R.P., C.P. Derse, B. Friedmann, S. Gillis, M. Plaut, M.L. Lichtenstein, and D.W. Mac Glashan, Jr. 1989. Regulation of human basophil mediator release by cytokines. I. Interaction with anti-inflammatory steroids. J. Immunol. 143:1310-1317.

61. Brunner, T., C.H. Heusser, and C.A. Dahinden. 1993. Human peripheral blood basophils primed by interleukin 3 (IL-3) produce IL-4 in response to immunoglobulin E receptor stimulation. J. Exp. Med. 177:605-611.

62. Carballido, J.M., A. Faith, N. Carballido-Perrig, and K. Blaser. 1997. The intensity of $\mathrm{T}$ cell receptor engagement determines the cytokine pattern of human allergen-specific Th cells. Eur. J. Immunol. 27:515-521. 